\title{
TRENDS IN TRAFFIC DELINQUENCY RATES IN THE REPUBLIC OF SERBIA
}

\begin{abstract}
Enforcement of radical legislative measures in order to improve traffic safety in the Republic of Serbia, which are implemented for some time, should result in a reduction of the rate of the traffic delinquency. This paper analyses trends in traffic delinquency rates in the Republic of Serbia with the aim to show trends of traffic delinquency rates by looking at the total number of traffic accidents and traffic offenses, the structure of traffic delinquency rates, as well as the share of traffic offenses within the overall crime in Serbia for period 2014-2018. The aim of this paper is to analyse the statistics, to obtain the right picture about existing situation, trends and structure of traffic delinquency, as well as about the effectiveness of preventive and repressive measures implemented, as well as the possible need to take further steps towards combating the traffic delinquency.
\end{abstract}

Keywords: traffic delinquency, traffic accidents, criminal offenses, traffic safety

\section{Introduction}

In modern society, taking before all into account continuous technical and technological development, special attention should be devoted to a devastating statistic data on number of traffic accidents and their consequences. Road safety at global level, as presented in reports of World Health

${ }^{*}$ MSc Lawyer, University of Pristina in Kosovska Mitrovica, Faculty of Technical Sciences PhD candidate of Faculty of Law for Commerce and Judiciary, Novi Sad, e-mail: aleksandra.petrovic@pr.ac.rs 
Organization $^{1}$, is associated with devastating statistical data. This fact marked period 2011-2020 as an Action Decade at global level. Similar conclusion could be drawn taking into account data on number of traffic accidents in the Republic of Serbia. This situation in not a novelty, but on the contrary, situation with which our society was faced for many years ${ }^{2}$, what initiated numerous attempts of social reaction, before all preventive ones, in order to increase awareness of traffic participants about the need to behave in traffic in disciplined way. The special, and for the thematic of this paper especially important approach to consideration of the traffic delinquency is legal approach. ${ }^{3}$ By enforcement of an organized protective system it was attempted to reduce the most serious consequences of traffic delicts, namely the number of casualties in road traffic in the Republic of Serbia, as well as significant material damages. As expected, emphasize was on prevention, through implementation of radical measures for all traffic participants. Republic of Serbia belongs to the group of states which generally accepted the idea to manage traffic safety, but in this sense, strong protective system was not yet implemented, consequence of which are numerous oscillations in number of casualties ${ }^{4}$. Creation of an adequate legal framework is prerequisite for implementation of system, aimed at enabling management of the traffic safety. ${ }^{5}$ Tightening of safety norms which regulate behaviour of traffic participants ${ }^{6}$ is visible through numerous

\footnotetext{
${ }^{1}$ Global status report on road safety 2015, World Health Organization (WHO). Downloaded from: https://scholar.google.com/scholar?hl=sr\&as_sdt=0\%2C5\&as_vis $=1 \& \mathrm{q}=$ world + health + organizati on + traffic + safety\&btnG $=$, accessed on 30 September 2019.

${ }^{2}$ Strategija bezbednosti saobraćaja na putevima Republike Srbije za period od 2015. do 2020. godine, Službeni glasnik RS, br. 64/15.

3 Dzunic, B., (2018). Preventive activities aimed at preventing and combating crime with the reference to the strategic framework of Republic of Serbia. Law - theory and practice (7-9), pp. 54.

${ }^{4}$ Ministry of Interior of the Republic of Serbia (2017, July) Strategic assessment of the public safety, Police Directorate, Belgrade, (25 September 2019). Downloaded from: http://www.mup. gov.rs/wps/wcm/connect/98632591-2b0d-4cba-9cd1 e7ff993705a6/Strateska+procena+javne+bez bednosti+konacno+za+internet $+\% 282 \% 29$.pdf?MOD=AJPERES\&CVID=1ThnbP0

${ }^{5}$ Road safety strategy of the Republic of Serbia for period 2015-2020 was adopted in 2015. Its basic goal is reduction of traffic accidents and mitigation of their consequences. It should contribute to the implementation of sustainable and efficient traffic safety management system until 2020, which will enable the following: since 2020 there are no casualties among children; annual number of casualties, seriously injured children and seriously injured adults in 2020 is halved in relation to 2011; total annual economic losses which are result of traffic accidents in 2020 are halved in relation to 2011.

${ }^{6}$ In addition to tightening of measures against traffic participants who break the law, there are numerous additional measures aimed at increasing of traffic safety. Some of them include: tightening of vehicle inspections, rules for driving test, probationary driving licenses etc.
} 
amendments of Road Safety Law (hereinafter: $\mathrm{RSL}^{7}$ ), with the goal to manage in efficient way abovementioned strategy. ${ }^{8}$

There are numerous criminogenic factors that influence the rate of traffic delinquency. They can be divided into three groups: behaviour of traffic participants, road condition and vehicles condition. Measures taken in order to improve traffic conditions are unavoidable and always implemented to the extent enabled by the economic situation of the state. Despite some positive actions implemented in the Republic of Serbia in relation with the road conditions and vehicles conditions, we can ascertain that the most important measures are implemented in order to influence on raising awareness and traffic culture of traffic participants.

Behaviour of traffic participants is the most important criminogenic factor of the traffic delinquency. There are numerous educational programs, campaigns, media promotions of the traffic safety, as well as other promotions aiming at raising discipline of traffic participants. However, despite some achieved positive results, there was no expectations that these can drastically influence the situation in this area'.

Repressive measures, penalties for traffic violations and criminal offences still remain necessary instruments for protection of society against crimes, in cases when other measures are insufficient for protection of specific social values, primarily human life and body. Violations of traffic legislation by traffic participants involve minor offenses or criminal responsibility. The purpose of repressive measures, primarily criminal ones, includes protection of specific social relations, and ultimately, protection of the whole society against criminality ${ }^{10}$. Number of traffic accidents, convicted persons and the structure of traffic delinquency are some of indicators of trends of traffic delinquency in the Republic of Serbia. Enforcement of radical legislative measures aiming to improve the traffic safety in the Republic of Serbia, which

\footnotetext{
7 Zakon o bezbednosti saobraćaja na putevima, Službeni glasnik RS, br. 41/2009, 53/2010, 101/2011, 32/2013 - odluka US, 55/2014, 96/2015 - dr. zakon, 9/2016 - odluka US, 24/2018, 41/2018, 41/2018 - dr. zakon, 87/2018 i 23/2019.

${ }^{8}$ Action plan for implementation of the Road safety strategy of the Republic of Serbia for period 2015-2020 (Official Gazette RS No. 1/2017). (2019, September 27) Downloaded from: https:// www.mgsi.gov.rs/sites/default/files/Akcioni\%20plan\%20za\%20sprovodjenje $\% 20$ Strategije $\% 20$ bezbednosti\%20saobracaja\%20na\%20putevima.pdf

${ }^{9}$ For more details please see: Brace, C., Whelan, M., Clark, B., Oxsley, J., (2009). The relationship between crime and road safety, Monash University, Accident Research Center, (2019, September 30) Downloaded from: https://www.politieacademie.nl/kennisenonderzoek/kennis/mediatheek/ PDF/75196.pdf

${ }^{10}$ Čejović, B., Kulić, M., (2014). Criminal Code, Novi Sad, The Business Academy, pp. 28.
} 
are implemented for some time, should result in a reduction of the rate of the traffic delinquency, as well as reduction of so called traffic crimes.

The aim of this paper is to present trends in traffic delinquency rates taking into account the total number of traffic accidents and number of legally processed criminal offenses against the traffic safety, the structure of traffic delinquency rates represented by number of traffic criminal offences, as well as the share of traffic criminal offenses within the overall crime in the Republic of Serbia for period 2014-2018. In relation with the abovementioned, it should be stressed that without having adequate and reliable data it is impossible to have the real picture of situation and trends of traffic delinquency in general, and consequently of implemented preventive and repressive measures, as well as possible need to amend them, or to enforce other legal measures.

At the end of this introduction it is necessary to explain the meaning of the term traffic delinquency. In this respect we can interpret traffic delinquency in narrow or broader meaning. Traffic delinquency interpreted in narrow meaning involves traffic crimes which includes so called "traffic criminal offenses" - criminal acts which include jeopardizing traffic safety ${ }^{11}$, while traffic delinquency interpreted in broader meaning, in addition to criminal delicts, includes traffic offenses as well. This different interpretation will be important for distinction of results presented in this paper. Prevailing forms of traffic delinquency in broader meaning are manifested in traffic accidents as a consequence of illegal behaviour which causes minor offence or criminal liability of traffic participants. Traffic accident is event with one or more casualties and/or with material damage. Mostly, traffic conflicts are caused by the mistake of drivers, as traffic participants. Prevailing traffic conflicts include: over speeding, improper overtaking, non-conceding the right of way and failure to keep sufficient distance ${ }^{12}$.

${ }^{11}$ Criminal acts against the traffic safety are foreseen in Chapter XXIV of the Criminal Code of the Republic of Serbia, Articles 289-297, including the following criminal acts: jeopardizing of the traffic safety (Article 289); jeopardizing of the traffic by dangerous act and dangerous tools (Article 290); endangering the air traffic safety (Article 291); endangering air traffic safety by violence (Article 292); hijacking of aircraft, ship and other mean of transportation (Article 293); piracy (Article 294); malpractice in supervision of public traffic (Article 295); failure to provide assistance to the person injured in traffic accident (Article 296) and serious criminal acts against traffic safety (Article 297).

${ }_{12}$ Bošković, M., Marković, M., (2015). Criminology with elements of victimology, Novi Sad, The Business Academy, pp. 286. 


\section{Research methods}

In this paper have been analysed statistical data about traffic accidents and persons convicted for criminal acts against the traffic safety gathered from annual and periodical reports of the Statistical institute of the Republic of Serbia. ${ }^{13}$.

This statistical data then underwent the qualitative and quantitative analysis of the content for period 2014-2018 in the Republic of Serbia. This period was taken into consideration in order to conduct analysis and monitor trends of the traffic delinquency rates in the Republic of Serbia. Data analysed in this paper cover the territory of the Republic of Serbia without the territory of Kosovo and Metohija.

In addition to the statistical method, during this research, methods of content analysis, empirical method, descriptive method, comparative method, as well as deduction and induction methods have been applied.

\section{Trends of traffic delinquency rates in period 2014-2018 in the Republic of Serbia}

Taking into account that ZOBS foresees radical measures for improvement of the road safety, it is important to take into consideration the total number of traffic accidents and ratio of the total number of traffic accidents and number of persons convicted for criminal acts against the traffic safety in period 2014-2018. On the basis of these data, it is possible to determine if the traffic delinquency rate declines and to come to the conclusion about efficiency of measures implemented in order to reduce the traffic delinquency in broader meaning. In addition to this, through analysis of statistical data for abovementioned period, it is possible to come to the conclusion about the percent of traffic criminal delicts in relation to the total number of traffic delicts. Such results could be obtained if we compare statistical data about the total number of road accidents and number of persons convicted for criminal acts against the traffic safety, in situations where the final verdict confirmed that the traffic criminal delict was committed.

Table 1 below presents annual number of adult persons convicted for criminal acts against traffic safety and number of traffic accidents in the Republic of Serbia in period 2014-2018.

\footnotetext{
${ }^{13}$ Statistical Institute of the Republic of Serbia, Available at: http://www.stat.gov.rs/
} 
Table 1: Number of traffic accidents and persons convicted for criminal acts against traffic safety ${ }^{14}$ in period 2014-2018

\begin{tabular}{|l|c|c|c|c|c|}
\hline Year & 2014 & 2015 & 2016 & 2017 & 2018 \\
\hline Number of traffic accidents & 13043 & 13638 & 14382 & 14691 & 14142 \\
\hline $\begin{array}{l}\text { Number of adults convicted for } \\
\text { criminal acts against traffic safety }\end{array}$ & 3461 & 2616 & 2176 & 2250 & 1974 \\
\hline
\end{tabular}

Source: Republic Statistical Institute. Publications ${ }^{15}$

By analysing presented data, we can deduct the following conclusions:

- Year 2014 is year with the lowest number of registered traffic accidents in the abovementioned period, or in other words year with the lowest rate of the traffic delinquency;

- Annual number of traffic accidents declines gradually in 2015 when compared with 2014, and then gradually raises during 2016, 2017 and 2018.

- The largest number of traffic accidents was registered in 2017

Obtained results cannot be taken as absolute comparable annually, but rather as relative ones, because there is dependency on other factors. The most

${ }_{14}$ Tables show number of adults convicted for crimes against the traffic safety.

15 Statistical Institute of the Republic of Serbia ( 2018). Publications. Registered road motor vehicles and trailers and road traffic accidents, Belgrade, (2019, September 21). Downloaded from: http://publikacije.stat.gov.rs/G2019/Pdf/G20191062.pdf

Statistical Institute of the Republic of Serbia (Belgrade, 2018). Publications. Registered road motor vehicles and trailers and road traffic accidents 2017. Downloaded from: http://publikacije.stat.gov. rs/G2018/Pdf/G20181063.pdf

Statistical Institute of the Republic of Serbia (Belgrade, 2016). Publications. Registered road motor vehicles and trailers and road traffic accidents 2016. Downloaded from: http://publikacije.stat.gov. rs/G2017/Pdf/G20171072.pdf

Statistical Institute of the Republic of Serbia (Belgrade 2015). Publications. Registered road motor vehicles and trailers and road traffic accidents 2015. Downloaded from: http://publikacije.stat. gov.rs/G2016/Pdf/G20161058.pdf Statistical Institute of the Republic of Serbia (Belgrade, 2019). Publications. Adult perpetrators of criminal acts 2018. Downloaded from: http://publikacije.stat. gov.rs/G2019/Pdf/G20191192.pdf Statistical Institute of the Republic of Serbia (Belgrade, 2018). Publications. Adult perpetrators of criminal acts 2017. Downloaded from: http://publikacije.stat. gov.rs/G2018/Pdf/G20181193.pdf

Statistical Institute of the Republic of Serbia (Belgrade, 2017). Publications. Adult perpetrators of criminal acts 2016. Downloaded from: http://publikacije.stat.gov.rs/G2017/Pdf/G20175629.pdf Statistical Institute of the Republic of Serbia (Belgrade, 2016). Publications. Adult perpetrators of criminal acts 2015. Downloaded from http://publikacije.stat.gov.rs/G2016/Pdf/G20161189.pdf Statistical Institute of the Republic of Serbia (Belgrade, 2015). Publications. Adult perpetrators of criminal acts 2014. Downloaded from: http://publikacije.stat.gov.rs/G2015/Pdf/G20155603.pdf 
important factor is primarily related to the increased number of registered motor vehicles in the Republic of Serbia, what causes increase of probability of traffic accidents. Improvement of road infrastructure and reduction of parts of roads marked as 'black holes' reduce the probability of traffic accidents.

When we look the ratio of number of traffic accidents and number of traffic criminal delicts, we can conclude that in period 2014-2018 number of traffic criminal delicts is in constant fall. Taking into account stagnation (in 2015) and gradual increase (2016-2018) of traffic delinquency rates in relation to 2014, we can conclude that the rate of the traffic criminality was reduced in 2018 to the half of percentage value when compared with 2014. This trend is shown in the following chart.

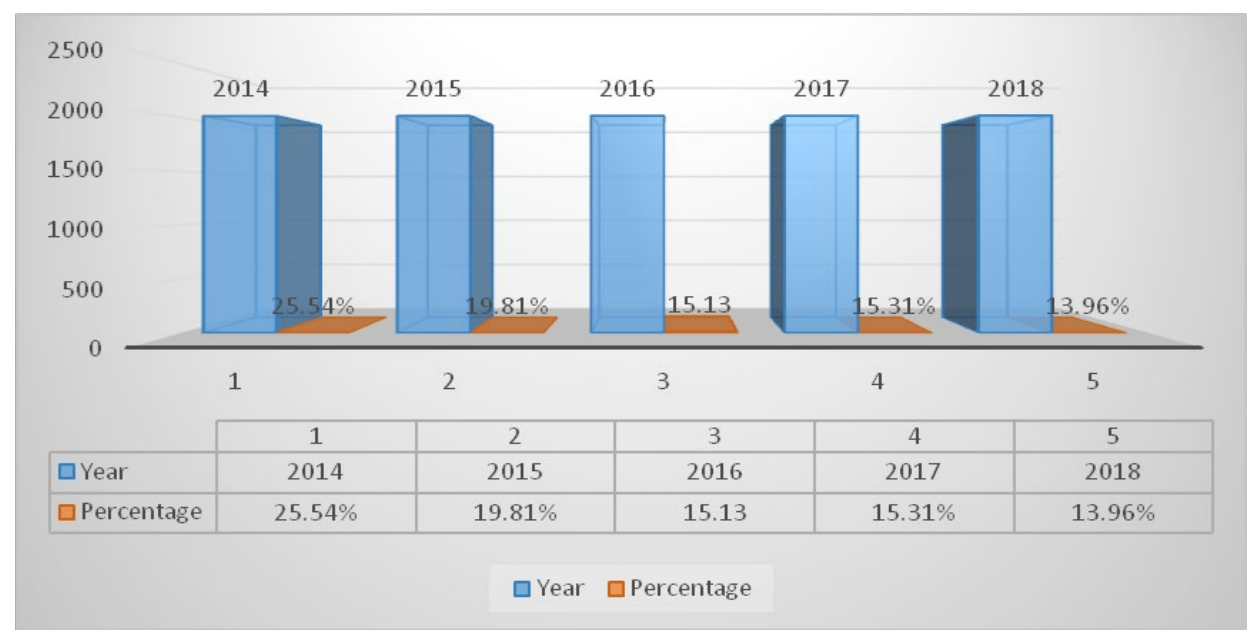

Chart 1. Percentage of traffic criminal delicts within the total number of traffic accidents

In order to have real picture of representation of traffic criminal delicts - traffic criminality in the total criminality in the Republic of Serbia, we will present and compare statistical data about total number of convicted adults and number of adults convicted for criminal acts against the traffic safety in the Republic of Serbia in period 2014-2018. Share of the traffic criminality within the total criminality in the Republic of Serbia in period 2014-2018 is presented in the following chart. 


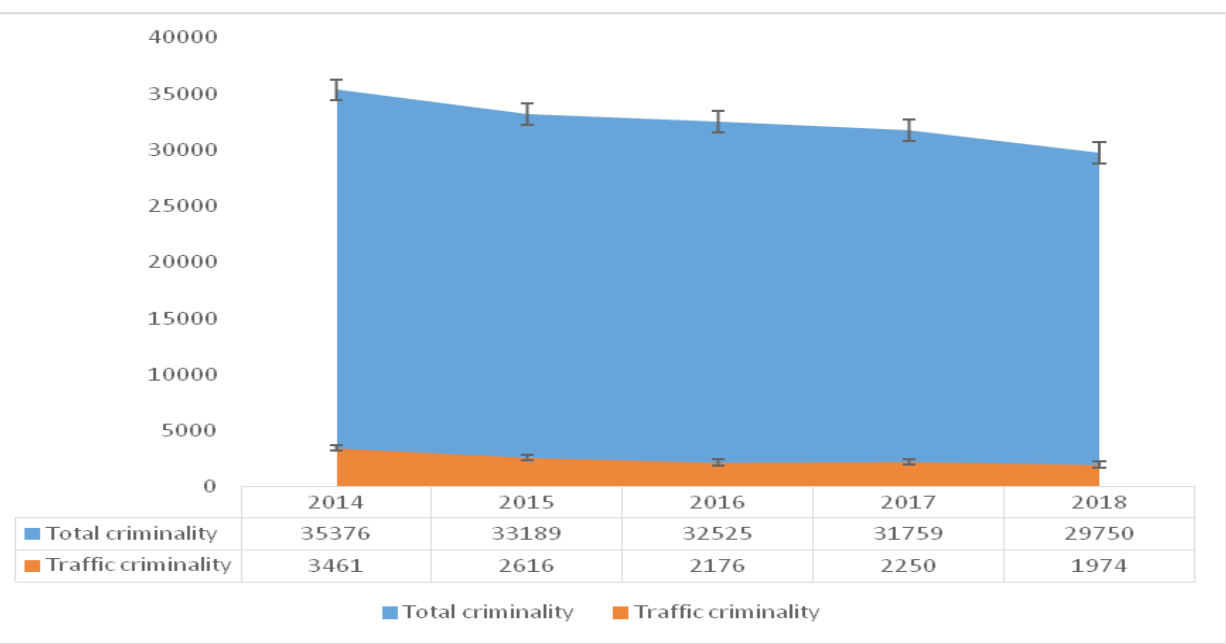

Chart 2: Share of traffic criminality within the total criminality in the Republic of Serbia in period 2014-2018

Annual percentage of the share of the traffic criminality within the total criminality in the abovementioned period is from $6.6 \%$ to $10.6 \%$. The bigger share in the total criminality have only crimes against property, marriage and family and against the human health.

For example:

- In 2014, number of persons convicted for criminal acts against the property was $31.8 \%$, and for criminal acts against the traffic safety was $9.8 \%$ (the second biggest percentage).

- In 2015, the fourth biggest share of $7.9 \%$ was for convicted persons for traffic crimes, while the biggest share of convicted persons $(34.1 \%)$ was for crimes against the property, then for crimes against the marriage and family $(10.6 \%)$ and for crimes against human health $(8.9 \%)$;

- In 2016, the fourth biggest share of $6.7 \%$ was for convicted persons for traffic crimes, while the biggest share of convicted persons $(34.7 \%)$ was for crimes against the property, then for crimes against the marriage and family (11.6\%) and for crimes against human health $(9.9 \%)$;

- In 2017, the fourth biggest share of $7.1 \%$ was for convicted persons for traffic crimes, while the biggest share of convicted persons $(32.5 \%)$ was for crimes against the property, then for crimes against the marriage and family (13.9\%) and for crimes against human health $(11.5 \%)$;

- In 2018, the fourth biggest share of $6.6 \%$ was for convicted persons for traffic crimes, while the biggest share of convicted persons $(29.6 \%)$ 
was for crimes against the property, then for crimes against the marriage and family (15.7\%) and for crimes against human health (13.9\%).

Looking at these percentages, we can conclude that the share of the traffic criminality within the total criminality, namely second biggest in 2014, and fourth biggest in 2015-2018, is significant, as well as that this share decreases in this period.

\section{Conclusion}

Taking into account introductory remarks and presented information about the traffic safety in modern societies and states, this paper starts from the presumption which is in favour of the fact that also in the Republic of Serbia there is a need to decrease the traffic delinquency rates. Data on the number of traffic accidents, number of convicted persons for crimes against traffic safety as an index of traffic delinquency rates in broader sense, then share of traffic crimes within the total criminality in the Republic of Serbia offered important information about trends and structure of traffic delinquency rates in the period observed.

Based on these results, we can conclude how efficient have been measures undertaken in order to improve the traffic safety. Absolute indexes show that traffic delinquency trends in broader sense is in slight decrease, while the traffic criminality rate decreases in relation to the total number of traffic delicts, for the period since 2014. The share of the traffic criminality within the total criminality for period 2014-2018 in the Republic of Serbia slightly decreased in relation to 2014.

Based on abovementioned conclusions, we can confirm the statement from the introductory part of this paper that the traffic delinquency is one of problems that requires special attention. Despite some positive results in the field of the traffic safety management, what was also confirmed with results obtained through data analysis presented in this paper, we can conclude that traffic safety problem requires long term and extensive efforts within society. Among them is surely more efficient and more consistent implementation of applicable legislation, in order to fully realise goals for which these measures have been enforced, and to reduce the illegal traffic behaviour to the lowest rate, what would cause decrease of the traffic delinquency and realisation of goals envisaged in the Traffic safety strategy. 


\section{Petrović Aleksandra}

Doktorand, Pravni fakultet za privredu i pravosuđe, Univerziteta Privredna akademija u

Novom Sadu, master pravnik, Fakultet tehničkih nauka, Kosovska Mitrovica

\section{KRETANJE STOPE SAOBRAĆAJNE DELINKVENCIJE U REPUBLICI SRBIJI}

\section{Re zime}

Preduzimanje radikalnih zakonodavnih mera u cilju unapređenja bezbednosti saobraćaja u Republici Srbiji, koje se primenjuju izvesno vreme, trebalo bi da rezultira smanjenjem stope saobraćajne delinkvencije. U radu je analizirano kretanje stope saobraćajne delinkvencije u Republici Srbiji sa ciljem da se prikažu trendovi stope saobraćajne delinkvencije, kroz sagledavanje ukupnog broja saobraćajnih nezgoda i broja saobraćajnih krivičnih delikata, struktura stope saobraćajne delinkvencije, kao i udela saobraćajnih krivičnih delikata u ukupnom kriminalitetu u Republici Srbiji za period od 2014 do 2018. godine. Cilj ovog rada je da se analiziranjem određenih statističkih podataka stekne prava slika o stanju, trendovima i strukturi saobraćajne delinkvencije, a samim tim i o efikasnosti preventivnih i represivnih mera koje se sprovode, kao i eventualnoj potrebi preduzimanja daljih koraka u pravcu suzbijanja saobraćajne delinkvencije.

Ključne reči: saobraćajna delinkvencija, saobraćajne nezgode, krivična dela, bezbednost javnog saobraćaja

\section{Literatura}

1. Bošković, M., Marković, M., (2015). Kriminologija sa elementima viktimologije, Novi Sad, Univerzitet Privredna akademija

2. Brace, C., Whelan, M., Clark, B., Oxsley, J., (2009). The relationship between crime and road safety, Monash University Accident Research Center, December. Downloaded from: https://www.politieacademie.nl/ kennisenonderzoek/kennis/mediatheek/PDF/75196.pdf

3. Čejović, B., Kulić, M., (2014). Krivično pravo, Novi Sad, Univerzitet Privredna akademija 
4. Krivični zakonik Republike Srbije, Službeni glasnik $R S$ broj $85 / 2005$, 88/2005-ispr., 107/2005-ispr., 72/2009, 111/2009, 121/2012, 104/2013, $108 / 2014$ i $94 / 2016$

5. Ministarstvo unutrašnjih poslova Republike Srbije (Beograd 2017). Strateška procena javne bezbednosti, direkcija policije, Preuzeto sa: http://www.mup.gov.rs/wps/wcm/connect/98632591-2b0d-4cba-9cd1e7ff993705a6/Strateska+procena+javne+bezbednosti+konacno+za+inter net $+\% 282 \% 29$.pdf?MOD=AJPERES\&CVID $=1$ ThnbP0

6. Republički zavod za statistiku (Beograd 2019). Publikacije. Punoletni ucinioci krivičnih dela 2018. Preuzeto sa: http://publikacije.stat.gov.rs/ G2019/Pdf/G20191192.pdf

7. Republički zavod za statistiku (Beograd 2018). Publikacije. Punoletni ucinioci krivičnih dela 2017. Preuzeto sa: http://publikacije.stat.gov.rs/ G2018/Pdf/G20181193.pdf

8. Republički zavod za statistiku (Beograd 2017). Publikcije. Punoletni ucinioci krivičnih dela 2016. Preuzeto sa: http://publikacije.stat.gov.rs/ G2017/Pdf/G20175629.pdf

9. Republički zavod za statistiku (Beograd 2016). Publikacije. Punoletni ucinioci krivičnih dela 2015. Preuzeto sa http://publikacije.stat.gov.rs/ G2016/Pdf/G20161189.pdf

10. Republički zavod za statistiku ( Beograd 2015). Publikacije. Punoletni ucinioci krivičnih dela 2014. Preuzeto sa: http://publikacije.stat.gov.rs/ G2015/Pdf/G20155603.pdf

11. Republički zavod za statistiku (Beograd 2019). Publikacije. Registrovana drumska motorna i priključna vozila i saobraćajne nezgode na putevima 2018. Preuzeto sa: http://publikacije.stat.gov.rs/G2019/Pdf/G20191062. pdf

12. Republički zavod za statistiku (Beograd 2018). Publikacije.Registrovana drumska motorna i priključna vozila i saobraćajne nezgode na putevima 2017.Preuzeto sa: http://publikacije.stat.gov.rs/G2018/Pdf/G20181063. pdf

13. Republički zavod za statistiku (Beograd 2016). Publikacije. Registrovana drumska motorna i priključna vozila i saobraćajne nezgode na putevima 2016.Preuzeto sa: http://publikacije.stat.gov.rs/G2017/Pdf/G20171072. pdf

14. Republički zavod za statistiku (Beograd 2015). Publikacije.Registrovana drumska motorna i priključna vozila i saobraćajne nezgode na putevima 2015. Preuzeto sa: http://publikacije.stat.gov.rs/G2016/Pdf/G20161058. pdf 
15. World Health Organization, Global status report on road safety 2015, preuzeto sa: https://scholar.google.com/scholar?hl=sr\&as_sdt=0\%2C5\&as_vi $\mathrm{s}=1 \& \mathrm{q}=$ world + health + organization + traffic + safety \&btnG $=$

16. Zakon o bezbednosti saobraćaja na putevima, Službeni glasnik $R S$ broj 41/2009, 53/2010, 101/2011, 32/2013-odluka US, 55/2014, 96/2015dr. Zakon, 9/2016- odluka US, 24/2018, 41/2018, 41/2018- dr. zakon, $87 / 2018,23 / 2019$ 